Clim. Past, 9, 2073-2084, 2013

www.clim-past.net/9/2073/2013/

doi:10.5194/cp-9-2073-2013

(C) Author(s) 2013. CC Attribution 3.0 License.

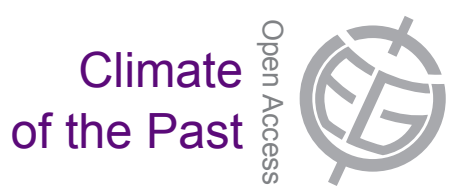

\title{
Long-term variations in Iceland-Scotland overflow strength during the Holocene
}

\author{
D. J. R. Thornalley ${ }^{1}$, M. Blaschek ${ }^{2}$, F. J. Davies $^{2}$, S. Praetorius ${ }^{3}$, D. W. Oppo ${ }^{1}$, J. F. McManus ${ }^{4}$, I. R. Hall ${ }^{5}$, \\ H. Kleiven ${ }^{6}$, H. Renssen ${ }^{2}$, and I. N. McCave ${ }^{7}$ \\ ${ }^{1}$ Department of Geology and Geophysics, Woods Hole Oceanographic Institution, Woods Hole, MA 02543, USA \\ ${ }^{2}$ Department of Earth Sciences, Faculty of Earth and Life Sciences, VU University Amsterdam, \\ 1081HV Amsterdam, the Netherlands \\ ${ }^{3}$ College of Oceanic and Atmospheric Sciences, Oregon State University, Corvallis, OR 97331-5503, USA \\ ${ }^{4}$ Department of Earth and Environmental Sciences, Lamont-Doherty Earth Observatory of Columbia University, Palisades, \\ NY 10964, USA \\ ${ }^{5}$ School of Earth and Ocean Sciences, Cardiff University, Cardiff, UK \\ ${ }^{6}$ Department of Earth Science, University of Bergen, Allegaten 41, 5007 Bergen, Norway \\ ${ }^{7}$ Department of Earth Sciences, University of Cambridge, Cambridge, UK
}

Correspondence to: D. J. R. Thornalley (d.thornalley@cantab.net)

Received: 5 March 2013 - Published in Clim. Past Discuss.: 26 March 2013

Revised: 8 July 2013 - Accepted: 15 July 2013 - Published: 3 September 2013

\begin{abstract}
The overflow of deep water from the Nordic seas into the North Atlantic plays a critical role in global ocean circulation and climate. Approximately half of this overflow occurs via the Iceland-Scotland (I-S) overflow, yet the history of its strength throughout the Holocene $(\sim 0-11700 \mathrm{yr}$ ago, ka) is poorly constrained, with previous studies presenting apparently contradictory evidence regarding its longterm variability. Here, we provide a comprehensive reconstruction of I-S overflow strength throughout the Holocene using sediment grain size data from a depth transect of 13 cores from the Iceland Basin. Our data are consistent with the hypothesis that the main axis of the I-S overflow on the Iceland slope was shallower during the early Holocene, deepening to its present depth by $\sim 7 \mathrm{ka}$. Our results also reveal weaker I-S overflow during the early and late Holocene, with maximum overflow strength occurring at $\sim 7 \mathrm{ka}$, the time of a regional climate thermal maximum. Climate model simulations suggest a shoaling of deep convection in the Nordic seas during the early and late Holocene, consistent with our evidence for weaker I-S overflow during these intervals. Whereas the reduction in I-S overflow strength during the early Holocene likely resulted from melting remnant glacial ice sheets, the decline throughout the last $7000 \mathrm{yr}$ was caused by an orbitally induced increase in the amount of Arctic sea
\end{abstract}

ice entering the Nordic seas. Although the flux of Arctic sea ice to the Nordic seas is expected to decrease throughout the next century, model simulations predict that under high emissions scenarios, competing effects, such as warmer sea surface temperatures in the Nordic seas, will result in reduced deep convection, likely driving a weaker I-S overflow.

\section{Introduction}

Oceanic processes occurring in the Nordic seas play a critical role in regulating global climate. The cooling of relatively salty water in the Arctic and Nordic seas causes the formation of cold, dense, intermediate and deep waters, which overflow the Greenland-Scotland Ridge ( 400-800 m water depth) into the Atlantic Ocean as Denmark Strait Overflow Water (DSOW, $\sim 3 \mathrm{~Sv}\left(10^{6} \mathrm{~m}^{3} \mathrm{~s}^{-1}\right)$, Greenland-Iceland Ridge) and Iceland-Scotland Overflow Water (ISOW, $\sim 3 \mathrm{~Sv}$, IcelandScotland Ridge) (Hansen and Osterhus, 2000) (Fig. 1). The driving force for the overflows is the vertically integrated pressure difference above the sill depth between the upstream (Nordic seas) and downstream (North Atlantic) sides (Hansen et al., 2001). This pressure gradient depends on numerous factors: the formation of cold, dense, intermediate 
a

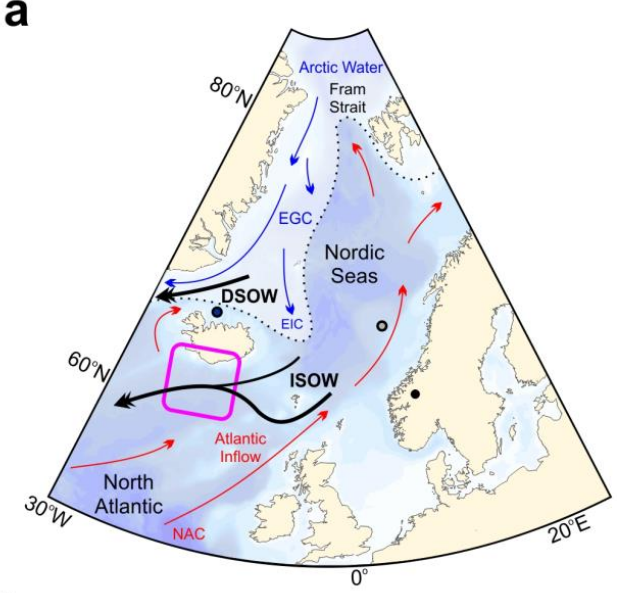

b

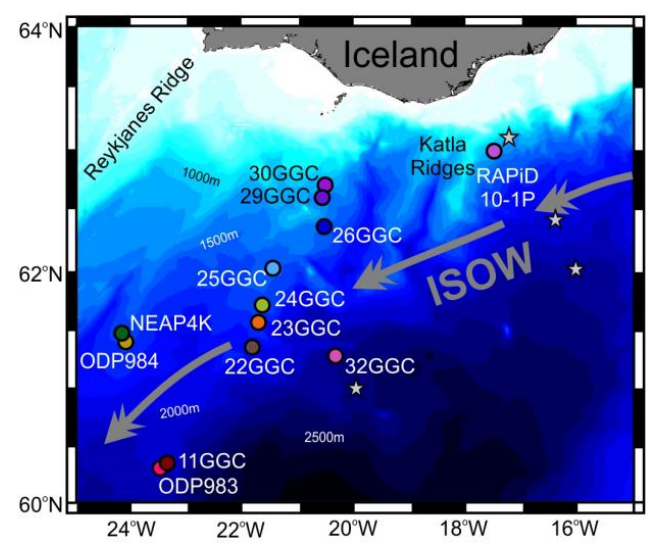

C
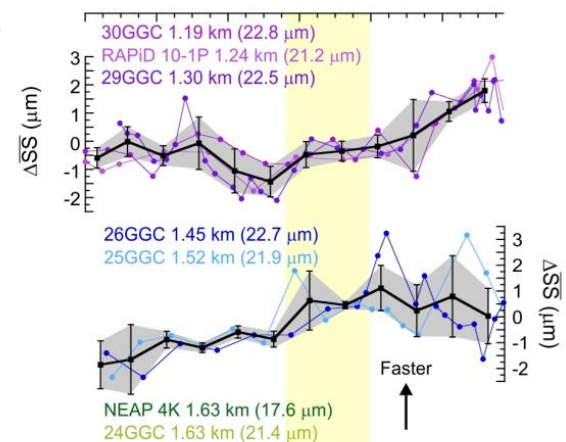

24GGC $1.63 \mathrm{~km}(21.4 \mu \mathrm{m})$

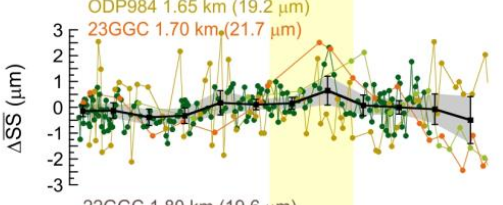

22GGC $1.80 \mathrm{~km}(19.6 \mu \mathrm{m})$ $11 \mathrm{GGC} 1.98 \mathrm{~km}(18.8 \mu \mathrm{m})$ ODP983 $1.98 \mathrm{~km}(17.9 \mu \mathrm{m})$

$32 \mathrm{GGC} 2.26 \mathrm{~km}(28.8 \mu \mathrm{m})$

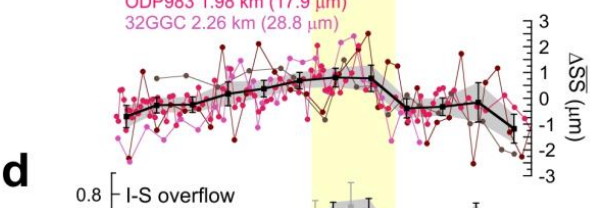

d

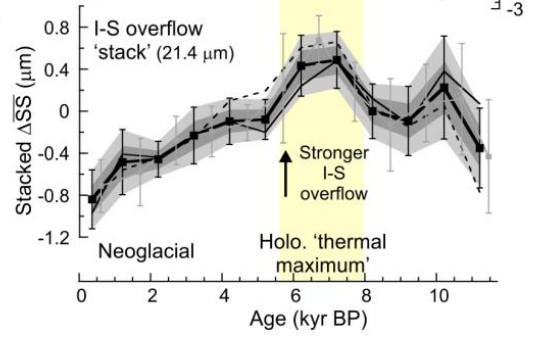

Fig. 1. (a) Regional map: thin red arrows are warm surface Atlantic waters; thin blue arrows are cold, fresh sea ice bearing Arctic surface waters; thick black lines are deep overflow pathways; purple square is the South Iceland Rise, ISOW flow speed proxy data; blue circle is the North Iceland drift-ice study site; grey circle is the Norwegian Sea sea-surface temperature study site; black circle is the Norwegian glacier record). (b) Map of core sites (see Table S2 for details): grey stars indicate the location of current meters used in SS core-top calibration (note that one additional site lies to the east of this map view). The main flow of ISOW is concentrated at 1400-1800 m over the East Katla Ridge (Shor, 1980) and at $\sim 1800 \mathrm{~m}$ water depth over Bjorn Drift $\left(\sim 22-24^{\circ} \mathrm{W}\right)$ (Bianchi and McCave, 2000). (c) Down-core changes in SS divided into 4 groups according to water depth (1200-1375 m, 1375-1575 m, 1575-1750 m, and 1750-2250 m). To enable comparison between cores, data are plotted with the mean Holocene value for each core (provided in parentheses) set to zero. Thick black line and symbols in each depth group illustrates the long-term trends described by the $1000 \mathrm{yr}$ "binned" data, with standard error bars ( \pm 2 SE). (d) Stacked data represent the relative strength of the Iceland-Scotland overflow, weighted according to the approximate depth interval each group represents (i.e. a weighting for the 4 groups, from shallow to deep, of 1.75, 2, 1.75, and 5). Error bars ( $\pm 2 \mathrm{SE})$ are calculated by propagating the standard errors from the grouped data, light grey shading $( \pm 2 \mathrm{SE})$, dark grey shading $( \pm 1 \mathrm{SE})$. Thin grey line and grey symbols (with accompanying grey \pm 2 SE error bars) is the "stack" obtained by offsetting the $1000 \mathrm{yr}$ bin windows by $500 \mathrm{yr}$ (see Fig. S1). Dashed line is the weighted average only using cores $>1.3 \mathrm{~km}$, the depth influenced by the modern I-S overflow (Bianchi and McCave, 2000); whilst the thin black line is the "stack" obtained from simply averaging the data from all the cores individually, rather than taking a weighted average of the 4 different depth intervals.

and deep waters north of the sill, the density of downstream waters at the sill, as well as the sea surface height difference (barotropic pressure gradient) across the sill, which is sensitive to wind-driven forcing (Hansen and Osterhus, 2000; Hansen et al., 2001; Biastoch et al., 2003; Olsen et al., 2008).

The overflows supply the densest waters to North Atlantic Deep Water (NADW) and contribute to approximately one-third of the volume transport of the deep branch of the Atlantic Meridional Overturning Circulation (AMOC), with the remaining two-thirds coming approximately equally from entrainment processes and Labrador Sea convection (forming Labrador Sea Water, LSW) (Hansen and Osterhus, 2000). The compensating inflow of warm surface Atlantic water causes substantial regional warming (up to 3$6^{\circ} \mathrm{C}$ north of $60^{\circ} \mathrm{N}$ ), therefore helping control ice-sheet balance, sea-ice extent and the climate of Northwest Europe 
(Hansen and Osterhus, 2000; Seager et al., 2002). Model simulations and palaeoclimate reconstructions indicate that a reduction or collapse in the overflow of deep water from the Nordic seas would have substantial, widespread, climate impacts (Vellinga and Wood, 2002; Solomon et al., 2007; Delworth and Zeng, 2012). Although modern hydrographic data reveal that the Nordic sea overflows have been relatively stable during recent decades, notwithstanding a possible reduction of up to $\sim 20 \%$ during the late 1960 s to early 1970s (Bacon, 1998; Olsen et al., 2008), we have limited knowledge of the longer term behaviour of the overflows (Bianchi and McCave, 1999; Rasmussen et al., 2002; Hall et al., 2004; Hoogakker et al., 2011; Kissel et al., 2013) and whether or not they have remained stable throughout the current interglacial - the Holocene $(0-11.7$ thousand years before present (ka)) (for details, see following section - Previous studies). This uncertainty limits our ability to assess the role that changes in the Nordic sea overflow may have had on regional and global climate evolution throughout the Holocene.

There is a broad consensus that the AMOC and the Nordic sea overflows weaken in response to relatively brief (multicentennial) but large freshwater perturbations such as those associated with the large Northern Hemisphere ice sheets of the last glacial (e.g. Heinrich events and the catastrophic release of proglacial Lake Agassiz at $\sim 8.2 \mathrm{ka}$, from both modelling (Vellinga and Wood, 2002; Stouffer et al., 2006; Smith and Gregory, 2009) and proxy studies (Ellison et al., 2006; Kissel et al., 2008; Gherardi et al., 2009)). These studies are important for examining the sensitivity of models and past climates to freshwater. However, future changes in freshwater fluxes, such as those predicted from the enhanced melting of the Greenland Ice Sheet (GIS) or changes in the hydrologic cycle in response to higher greenhouse gases (GHGs), are expected to be smaller, yet they may occur over a more prolonged period and be combined with warming high latitude sea-surface temperatures (SSTs) (Solomon et al., 2007). It is therefore pertinent to improve our knowledge of the AMOC and Nordic sea overflow during past warm climate intervals. In this study we provide new constraints on Iceland-Scotland (I-S) overflow strength throughout the Holocene. This epoch includes a range of climate forcings, including orbitally induced changes in insolation and enhanced deglacial meltwater input prior to $\sim 7 \mathrm{ka}$.

\section{Previous studies}

Many studies have examined the causes and mechanisms of abrupt centennial-millennial scale climate events in the North Atlantic during the Holocene (e.g. see reviews by Mayewski et al., 2004; Wanner et al., 2008, 2011). However, the focus of this study is on investigating the long-term evolution of the I-S overflow during the Holocene and its links to subpolar North Atlantic climate, which can be broadly characterized by a regional mid-Holocene "thermal maximum" (HTM, e.g. Marchal et al., 2002), and a late Holocene increase in sea ice (Andrews et al., 2009) and glacier advance (Nesje et al., 2001) in the Nordic seas and surrounding regions, termed the "neoglaciation" (Porter and Denton, 1967). Previous work suggests that these climate changes were coupled with complex reorganizations in the surface circulation of the North Atlantic that likely impacted deep water formation and circulation (Risebrobakken et al., 2003; Solignac et al., 2004; Moros et al., 2006; Thornalley et al., 2009; Giraudeau et al., 2010).

To determine the timing and nature of reorganization of deep North Atlantic circulation, a variety of techniques have been used, including benthic foraminiferal isotopes, faunal proxies and bulk sediment mineralogy, from which the extent of water masses and circulation pathways may be inferred. For example, records from sites influenced by LSW suggest that strong LSW formation similar to the present day started at $\sim 7-8 \mathrm{ka}$ and then underwent subsequent millennial-scale oscillations in its strength (Hillaire-Marcel et al., 2001; Oppo et al., 2003; Olsen and Ninnemann, 2010). Data on the bulk mineralogy and geochemical provenance of clays have been used to argue for an increased contribution of ISOW to the deep North Atlantic at $\sim 6 \mathrm{ka}$, and a reinforcement of waters formed in the Norwegian Sea over the last $3 \mathrm{ka}$ (Fagel and Mattielli, 2011). This interpretation is in apparent conflict with results from benthic foraminiferal isotopes, faunal proxies, grain size and magnetic susceptibility, which have been used instead to infer a decline in the influence of ISOW and Northeast Atlantic Deep Water (to which ISOW is a major contributor) over the past $\sim 6.5 \mathrm{ka}$, both in the deep Northeast Atlantic (Rasmussen et al., 2002; Hoogakker et al., 2011; Kissel et al., 2013) and Northwest Atlantic (Bilodeau et al., 1994; Hoogakker et al., 2011). (However the changes in the northwest may also be attributed to an increase in the supply of Northwest Atlantic Deep Water (fed by DSOW) to the western basin.) A decline in deep water formation in the Nordic seas would be in agreement with Holocene climate model simulations of deep water formation trends (Renssen et al., 2005).

Other studies have used alternative techniques to investigate changes in physical circulation rates of the deep North Atlantic: sedimentary ${ }^{231} \mathrm{~Pa} /{ }^{230} \mathrm{Th}$ ratios may reflect the rate of southward advection of deep water from the North Atlantic. Although only low-resolution Holocene ${ }^{231} \mathrm{~Pa} /{ }^{230} \mathrm{Th}$ records exist (McManus et al., 2004; Gherardi et al., 2009), these data nevertheless suggest stronger export of water at depths shallower than $\sim 3 \mathrm{~km}$ during the early Holocene, while deeper sites indicate a gradual increase and then little change after $\sim 8 \mathrm{ka}$. Geostrophic estimates based on benthic $\delta^{18} \mathrm{O}$ from Florida Straits (Lynch-Stieglitz et al., 2009) instead suggest that there has been no dramatic change in the northward-flowing upper limb of the AMOC over the last $8 \mathrm{ka}$, although, by itself, this evidence cannot be used to infer variability in the deep overflows, or lack thereof, because of 
alternative return pathways (i.e. LSW formation, entrainment processes and upper mid-ocean and Ekman transport). Each of these proxies has its limitations and has been challenged (Huybers and Wunsch, 2010); therefore, other estimates of flow rate are needed.

Several proxies have been used to estimate changes in the physical strength of deep-sea currents directly, including the "sortable silt" mean grain size ( $\overline{\mathrm{SS}}$, where coarser mean grain sizes indicate faster near-bottom current flow speeds) (Bianchi and McCave, 1999; Hall et al., 2004; Praetorius et al., 2008; Hoogakker et al., 2011; Kissel et al., 2013) and sediment magnetic properties (Kissel et al., 2008, 2009, 2013). Early studies using these techniques revealed significant centennial-to-millennial scale variability in the flow speed of ISOW (Bianchi and McCave, 1999; Hall et al., 2004), but little, or no, overall long-term trend. In contrast, several more recent studies have suggested a gradual longterm decline in ISOW strength through the Holocene (Kissel et al., 2009, 2013; Hoogakker et al., 2011). This apparent conflict is probably caused by a number of factors: (1) existing grain size records have been restricted to one or two core sites, which do not adequately constrain the possible influence of vertical migrations of the main axis of the overflow on the palaeocurrent reconstruction; (2) several of the grain size and magnetic property study sites are located towards the southern end of Gardar Drift (i.e. more distal to the overflow), where the variability in flow speed is substantially influenced by changes in the volume and properties of the water mixing with and overlying ISOW (mainly LSW) (Boessenkool et al., 2007); (3) the abundance of magnetic grains may also be controlled by variability in the source supply (Kissel et al., 2009) (a problem not affecting $\overline{\text { SS }}$ at suitable drift sites; McCave and Hall, 2006); recent work, however, suggests that source supply variability is not the primary control on the supply of magnetic grains to Gardar Drift (Kissel et al., 2013).

\section{Proxy reconstruction of I-S overflow strength}

\subsection{Methods}

In this work, we analyse $\overline{\mathrm{SS}}$ grain size in 13 sediment cores located on the South Iceland Rise and Bjorn Drift (see Fig. 1). The improvement from previous studies is significant because the large number of cores we use, which span $\sim 1200 \mathrm{~m}$ to $2300 \mathrm{~m}$ water depth and therefore bracket the main flow axis of ISOW found at $\sim 1800 \mathrm{~m}$ (Bianchi and McCave, 2000), allows us to determine fully the changes in both the relative strength and vertical shifts of the I-S overflow. Furthermore, we have selected sites located close to the I-S Ridge, in order to minimize the variability in flow speed caused by downstream mixing with other water masses.

Age models were produced by linear interpolation between ${ }^{14} \mathrm{C}$-AMS dates of monospecific samples of planktonic foraminifera and the occurrence of the Vedde Ash (see the Supplement for a complete list of ${ }^{14} \mathrm{C}$ dates and depth of Vedde Ash in cores). Previously published SS data were used for NEAP-4K (Hall et al., 2004) and ODP 984 (Praetorius et al., 2008). All cores show relatively constant sedimentation rates throughout the Holocene (Fig. 2). They are characterized by high Holocene sedimentation rates (typically $5-50 \mathrm{~cm} \mathrm{ka}^{-1}$ ) of silty-clay lithologies with no foraminifera sand lag deposits present, which might be expected if winnowing was sufficiently active to form a hiatus. Sediment was prepared for $\overline{\mathrm{SS}}$ analysis using standard procedures (McCave and Hall, 2006). All data were analysed using a Sedigraph 5100 (except for NEAP-4K and RAPiD-101P, which were determined using a Beckman Coulter Multisizer III), using previously described techniques (Praetorius et al., 2008); SS measurements errors are less than $\pm 2 \%$ $(\sim 0.4 \mu \mathrm{m})$ (Bianchi et al., 1999).

Based on the lowest sampling resolution of $500-1000 \mathrm{yr}$, all data within individual depth groups were binned at $1000 \mathrm{yr}$ intervals. These $1000 \mathrm{yr}$ averages for each depth group were then combined to produce the final stacked record of I-S overflow strength, using several approaches, including both a depth-weighted stack and a simple averaging of binned data from all individual cores (see Fig. 1 for details and results). $1000 \mathrm{yr}$ bins were chosen because smaller bins (e.g. $500 \mathrm{yr}$ ) would result in numerous intervals for the grouped datasets that contained no data. Larger bins (e.g. $2000 \mathrm{yr}$ ) would incorporate more data and therefore produce more robust mean values, but would also reduce the resolution of the final stack and limit its usefulness for examining climate changes throughout the Holocene.

\subsection{Sensitivity tests}

The effect of altering the specific intervals for the $1000 \mathrm{yr}$ bins was investigated by using bins offset by $500 \mathrm{yr}$ (i.e. the most extreme case) from those originally used. The results for each depth group are shown in the Supplement Fig. S1 (and for the stacked record, the results are shown in Fig. 1d), illustrating that the overall trends are similar regardless of the specific intervals chosen.

We also note that the final stacked record is not very sensitive to the grouping of cores. The cores were grouped based on ascending water depth, with the precise boundaries for each group determined based on grouping cores with visually similar trends. To demonstrate that this grouping does not strongly affect the overall trend of the final stack, we produced a stack based simply on averaging the results from the individual cores (i.e. not subject to any grouping), and compared this with the stack produced by taking the weighted mean of the four depth intervals/groups (shown in Fig. 1d). The values for the individually averaged stack fall within \pm 1 standard error (SE) of the weighted stack, underscoring that the overall trends of the stack are not strongly dependant 


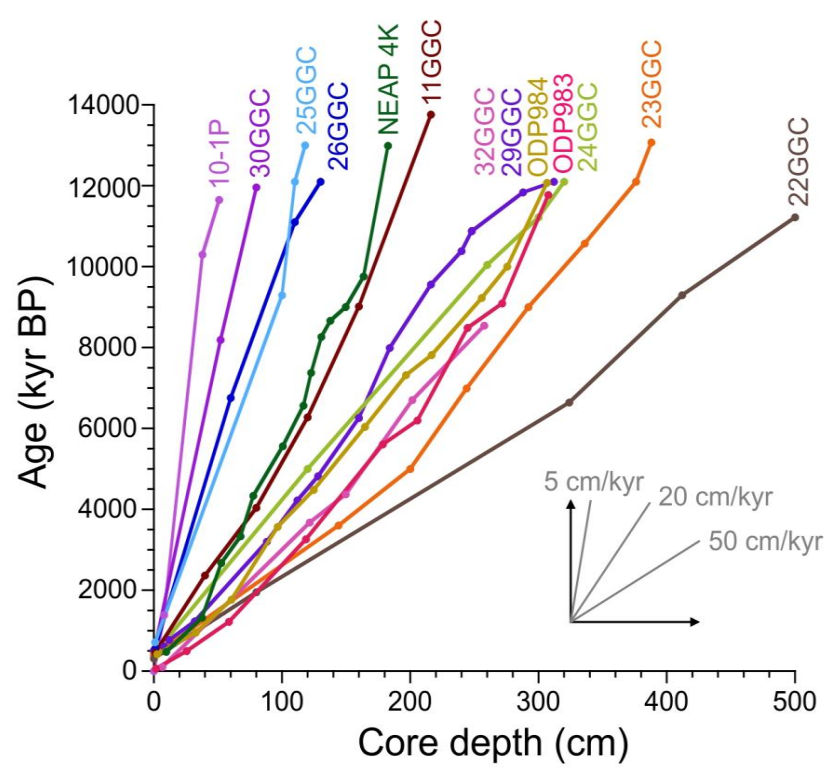

Fig. 2. Age models for sediment cores, based on linear interpolation between age control points.

on the precise method of averaging used (i.e. the choice of grouping and weighting).

\subsection{Calibration of sortable silt measurements}

In this study, changes in the $\overline{\mathrm{SS}}$ grain size (given in $\mu \mathrm{m}$ ) data are used to approximate the variability in flow speed at any given water depth. By binning the $\overline{\mathrm{SS}}$ data from several cores, we produce estimates of the flow speed change across a selected depth interval, or, by averaging all of the records, a "stack" representing the most likely overall changes in I-S overflow strength (calculated either by averaging all cores individually, or by taking a depth-weighted average of the four depth groups, and in one case, excluding the shallowest depth group which is not influenced by ISOW today - see Fig. 1d). This method assumes that the same magnitude change in grain size at any given core site represents a similar change in palaeocurrent flow speed. This therefore assumes an approximately linear relationship between $\overline{\mathrm{SS}}$ and the near-bottom current speed. There are limited suitable data to test the calibration of $\overline{\mathrm{SS}}$, partly because of the scarcity of long-term current meter data close to the seafloor from sites that are also suitable for conducting grain size analysis. (Many current meter arrays are set in the strongest flows which tend to either non-depositional or erosional environments.) The only published attempt to calibrate silt grain size (i.e. 2-63 $\mu \mathrm{m}$ ) changes (not, however, $\overline{\mathrm{SS}}$, which is $10-63 \mu \mathrm{m}$ ) does indicate an approximately linear relationship (Ledbetter, 1986).

There is an ongoing programme (led by I. N. McCave) to calibrate $\overline{\mathrm{SS}}$ changes to long-term ( $>1 \mathrm{yr}$ duration) current meter data. Sediment core-top $\overline{\mathrm{SS}}$ from the same site as current meter data taken from moorings $\sim 10-40 \mathrm{~m}$ above the

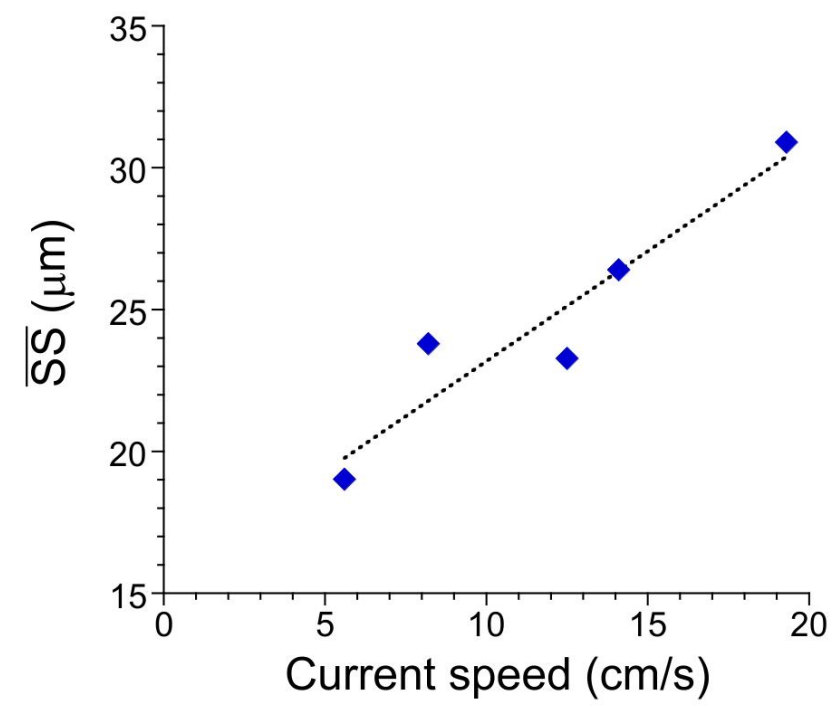

Fig. 3. Core-top $\overline{\mathrm{SS}}$ calibration for the northern Iceland Basin; $\overrightarrow{\mathrm{SS}}=15.4 \mu \mathrm{m}+0.78 U$, where $U$ is mean current speed (in $\mathrm{cm} \mathrm{s}^{-1}$ ) $\left(R^{2}=0.89, n=5, p=0.005\right)$.

seafloor within the northern Iceland Basin, and determined using a Sedigraph, are presented in Table 1 and Fig. 3. These sites are characterized by silty clay core tops of late Holocene age (Table S3). Similar to the earlier study (Ledbetter, 1986), the data suggest a linear relationship between $>1 \mathrm{yr}$ mean near-bottom flow speed and $\overline{\mathrm{SS}}$. Although only based on five calibration points, this relationship yields reasonable inferred flow speeds at our core sites and has the advantage of being based on data from the study area. For example, the average $\overline{\mathrm{SS}}$ values for our cores typically range from 18 to $23 \mu \mathrm{m}$, equating to flow speeds of $\sim 3-10 \mathrm{~cm} \mathrm{~s}^{-1}$ over eastern Bjorn Drift, which is in good agreement with observations and geostrophic estimates made in the region (Bianchi and McCave, 2000). One core in our Holocene dataset (32GGC, $2260 \mathrm{~m})$ has unusually coarse Holocene $\overline{\mathrm{SS}}$ values $(\sim 29 \mu \mathrm{m})$, suggesting speeds of $\sim 17 \mathrm{~cm} \mathrm{~s}^{-1}$, consistent with current speeds of $\sim 19 \mathrm{~cm} \mathrm{~s}^{-1}$ recorded at a mooring with a similar depth (2078 m, IB90/1) (Van Aken, 1995), located 50 km to the northeast, at the foot of West Katla Ridge, and likely caused by local topographic steering of the flow of ISOW (Shor, 1980; Van Aken, 1995).

Clearly, with the limited calibration dataset available, deriving absolute values of current speed should be approached with caution. However, the core top data help ground-truth the use of the $\overline{\mathrm{SS}}$ proxy in this region, support an earlier inference for an approximately linear relationship between flow speed and mean silt grain size, and allow us to estimate the approximate magnitude of the flow speed changes inferred from our grain size data. The programme to calibrate the $\overline{\mathrm{SS}}$ is ongoing and is extending similar core-top comparisons with current meter data throughout the global ocean. It should be stressed that, from early indications, it is by no 
Table 1. Core-top $\overline{\mathrm{SS}}$ calibration data, determined using a Sedigraph. Core-top ${ }^{14} \mathrm{C}$ ages (un-calibrated, no reservoir correction; Kristjansdottir et al., 2011).

\begin{tabular}{llrlrlrrr}
\hline & \multicolumn{9}{c}{$\begin{array}{l}\text { Mean } \\
\text { Refrent } \\
\text { meter }\end{array}$} & $\begin{array}{r}\text { speed } \\
\left(\mathrm{cm} \mathrm{s}^{-1}\right)\end{array}$ & $\begin{array}{l}\text { Core } \\
\text { RAPiD- }\end{array}$ & $\begin{array}{r}\text { Core-top } \\
{ }^{14} \mathrm{C}(\mathrm{yr})\end{array}$ & $\begin{array}{l}\text { Lat. } \\
\left({ }^{\circ} \mathrm{N}\right)\end{array}$ & $\begin{array}{r}\text { Long. } \\
\left({ }^{\circ} \mathrm{W}\right)\end{array}$ & $\begin{array}{r}\text { Depth } \\
(\mathrm{m})\end{array}$ & $\begin{array}{r}\overline{\mathrm{SS}} \\
(\mu \mathrm{m})\end{array}$ \\
\hline Dickson (1989) & IOS 1135 & 12.5 & $03-1 \mathrm{C}$ & 2134 & 59.9627 & 12.1622 & 1206 & 23.28 \\
Saunders (1996) & ACM8b 506 & 14.1 & $06-3 \mathrm{~B}$ & 707 & 62.0633 & 16.0557 & 2228 & 26.40 \\
Saunders (1996) & ACM8b 505 & 19.3 & $07-4 \mathrm{~B}$ & 574 & 62.4393 & 16.4663 & 2050 & 30.90 \\
Saunders (1996) & ACM8b 502 & 8.2 & $09-1 \mathrm{G}$ & 512 & 63.1398 & 17.2943 & 1038 & 23.80 \\
Van Aken (1995) & IB90/2 & 5.6 & $18-3 \mathrm{C}$ & 382 & 60.9877 & 19.9887 & 2407 & 19.02 \\
\hline
\end{tabular}

means evident that the calibration data shown here for the northern Iceland Basin can be applied to other ocean settings.

One potential obstacle to obtaining a universal flow speed calibration of $\overline{\mathrm{SS}}$ is the possibility that there may be downstream fining of sediment supply along the sediment transport pathway (McCave and Hall, 2006). This would therefore limit the ability of distal sites to record large changes in grain size because of the absence of coarser material for sorting supplied to the site (i.e. the dynamic range of the sortable silt proxy is more limited at these sites). A possible method to account for such site-specific variability could be to normalize the $\overline{\mathrm{SS}}$ data into units of standard deviation, so that grain size changes at sites with a limited dynamic range are given equivalence to larger grain size changes at sites with a larger dynamic range (e.g. Haskell et al., 1991; Thornalley et al., 2013).

Given that our study sites are located within a relatively small region, it is very unlikely that there is significant downstream fining. Regardless of this fact, if we normalize the data, the end result is extremely similar to that obtained using the "raw" data (see Supplement Fig. S2). This is because the down-core standard deviations of the $\overline{\mathrm{SS}}$ data are very similar for all the cores.

\section{Results and discussion}

\subsection{Holocene proxy reconstruction}

The results of our $\overline{\mathrm{SS}}$ analyses are presented in Fig. 1c, grouped according to water depth. Peak flow speed occurs in the shallow cores $(<1.3 \mathrm{~km})$ during the earliest Holocene and then declines, whereas the deeper cores indicate later flow speed maxima occurring at $\sim 8 \mathrm{ka}(\sim 1.5 \mathrm{~km})$ and $\sim 7 \mathrm{ka}(>1.5 \mathrm{~km})$ respectively (see Fig. 4). The progressive shift in the timing of the flow speed maxima with increasing water depth (i.e. deeper sites peak later) is consistent with the hypothesis that the main axis of ISOW flow over the Iceland slope deepened throughout the early Holocene (Thornalley et al., 2010). The vertical migration of the main flow axis of the I-S overflow must therefore be accounted for when trying to interpret any single record. For example, we

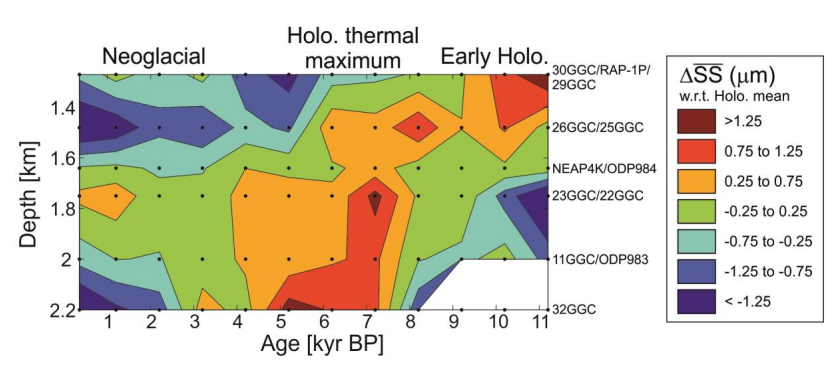

Fig. 4. Contour plot showing Holocene changes in $\overline{\mathrm{SS}}$ (i.e. inferred flow speed) across the depth transect of cores. There is a progressive shift in the timing of the inferred flow speed maxima with increasing water depth (i.e. deeper sites peak later).

suggest that the relatively low inferred flow speed in the early Holocene for the 1575-1750 m group reflects the position of these sites near the lower edge of the shallow I-S overflow during the early Holocene. A peak in flow at these sites is recorded at $\sim 7 \mathrm{ka}$ as the main flow of I-S overflow passes through this depth during its early Holocene deepening. Flow speed then decreases as these cores are located on the upper edge of the main flow of I-S overflow water through the remainder of the Holocene.

We suggest that shallow I-S overflow prior to $\sim 7-8 \mathrm{ka}$ may have been caused by the following: (i) a greater relative contribution of dense Lower Deep Water (of southern origin) to the ambient deep water of the Northeast Atlantic, limiting the depth to which ISOW could descend or (ii) a reduced density of ISOW formation waters. It is unlikely that the shallow overflow was caused by a reduced density of entrained subsurface water masses, since proxy records indicate that these were, instead, more dense during the early Holocene (Price and Baringer, 1994; Thornalley et al., 2009).

As previously discussed, in order to represent the overall changes in the relative strength of the I-S overflow through the Holocene, we have averaged, or "stacked", the $\overline{S S}$ data from the cores (Fig. 1d). Because this stack is based on an integrated set of flow speed reconstructions spanning the whole overflow, we suggest that it is also likely a robust estimate of the reduction in flux of the I-S overflow. The "stack" 
reveals that I-S overflow strength increased throughout the early Holocene, albeit with a local minimum at $\sim 9.5-8 \mathrm{ka}$. Peak overflow strength occurred at $\sim 7 \mathrm{ka}$, followed by a gradual decline throughout the remainder of the Holocene, as North Atlantic climate deteriorated into the Neoglacial. (The decline after $\sim 7 \mathrm{ka}$ can be described by a linear regression $\left(n=8, R^{2}=0.94, p,<0.001\right)$, or as a monotonic trend with the rank correlation coefficient, Kendall tau $=1$, $p<0.001$.) Uncertainty associated with the existing calibration limits confidence in quantifying this decline; nevertheless, it suggests a $\sim 20 \pm 20 \%$ reduction (from $\sim 8 \mathrm{~cm} \mathrm{~s}^{-1}$ to $\sim 6.5 \mathrm{~cm} \mathrm{~s}^{-1}$ ) in average flow speed of ISOW over our study region from $\sim 7 \mathrm{ka}$ to the late Holocene.

Because I-S overflow is driven by the pressure gradient across the ridge (Hansen and Osterhus, 2000), primarily resulting from deep and intermediate water formation in the Nordic seas, it is probable that changes in deep water formation underlie the observed long-term overflow variability. We consider it unlikely that the changes in overflow strength were caused by variable entrainment because (i) the volume of entrained water on the South Iceland Rise is relatively small (estimated at $\sim 25 \%$ ) (Hansen and Osterhus, 2000); (ii) density estimates for the entrained water mass close to the ridge (i.e. thermocline water) (Thornalley et al., 2009) do not reveal any similar long-term trends; (iii) the correlation between our I-S overflow stack and regional climate records suggests a coupled cross-ridge exchange of deep overflow waters and surface inflow waters (see Fig. 5).

Decreasing I-S overflow strength after $\sim 7 \mathrm{ka}$ is consistent with changes inferred from faunal assemblage time slice data from the Faroe-Shetland region (Rasmussen et al., 2002) and is in excellent agreement with recent reconstructions of ISOW flow strength along Gardar Drift using grain size and magnetic mineral proxies (Kissel et al., 2013). The results of Kissel et al. (2013) may hint at a slight plateau between $\sim 3$ and $5 \mathrm{ka}$, which would agree with the suggestion of a significant reorganization of deep water circulation at $\sim 3 \mathrm{ka}$ (Fagel and Mattielli, 2011); the uncertainty in our I-S overflow stack prevents us from confidently commenting on any such feature. We also observe that the changes in I-S overflow strength were closely coupled to regional climate on millennial timescales throughout the Holocene (Fig. 5), with warmer conditions occurring during intervals of stronger overflow, suggesting a causal link, which was likely the increase in compensating inflow of warm Atlantic surface waters to the region. In addition, warming was probably also caused by a coupled reduction in Nordic sea sea-ice cover (Renssen et al., 2009). Because the I-S overflow only accounts for approximately half of the total Nordic sea overflow, ongoing and future studies aim to constrain robustly long-term changes in the strength of the Denmark Strait (DS) overflow, to assess whether it had a similar history to the I-S overflow, thereby supporting our inference of a causal link between regional Holocene climate change and Nordic sea overflow strength; or, if instead, opposing trends in DS

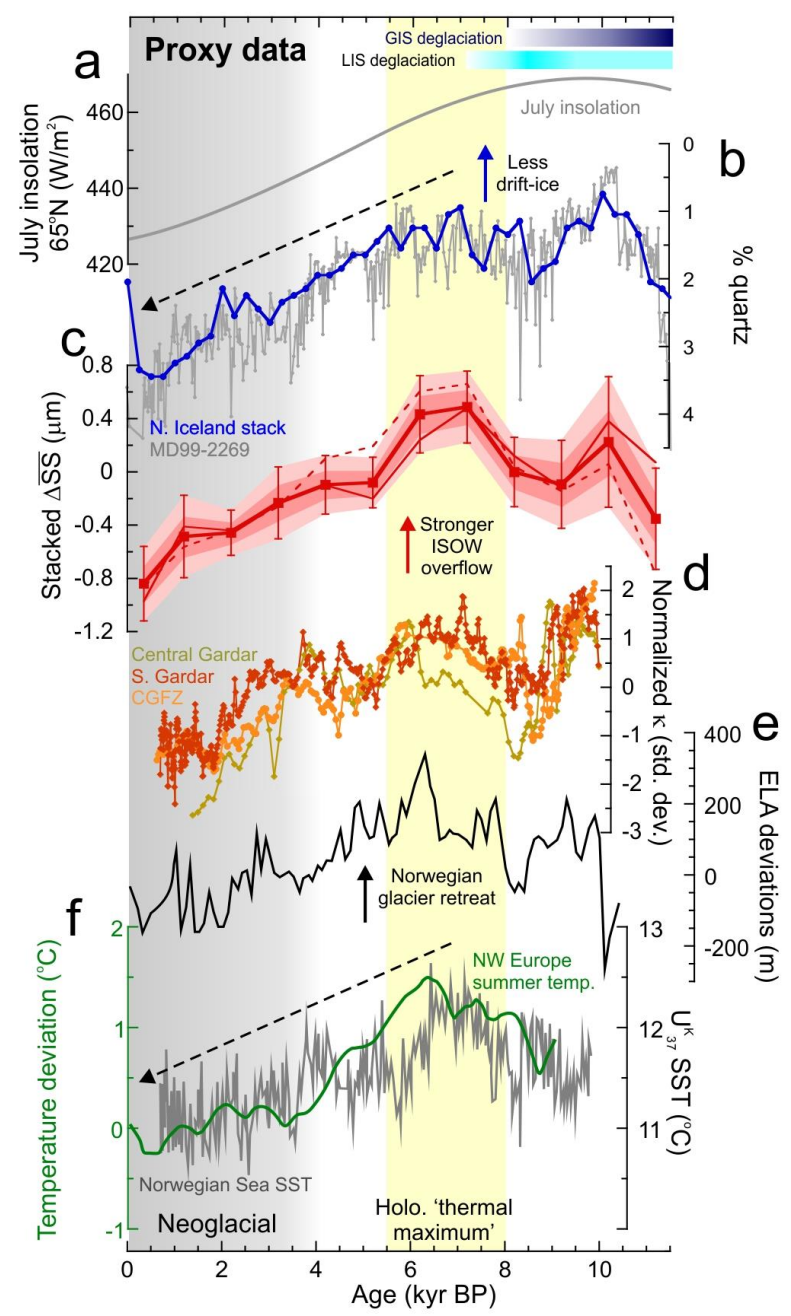

Fig. 5. Comparison between the estimated changes in IcelandScotland overflow strength and climate proxies: (a) coloured bars indicate intervals of ice sheet retreat (see the Supplement); grey line is July insolation at $65^{\circ} \mathrm{N}$; (b) percent abundance of quartz grains in North Iceland shelf sediment cores, a proxy for drift ice abundance (multi-year sea ice and ice bergs) within the East Greenland Current and East Icelandic Current advance (blue line, stack record including up to 20 cores (Andrews et al., 2009); grey line, high-resolution data (Moros et al., 2006) from core MD99-2269); (c) Iceland-Scotland overflow strength (as in Fig. 1d, although the plot of the $500 \mathrm{yr}$ offset bins has been excluded to simplify the plot); (d) magnetic susceptibility data, interpreted as a proxy for the flow strength of ISOW along Gardar Drift (data for each individual core have been normalized to aid comparison on a single plot; data from two cores located at Charlie Gibbs Fracture Zone (CGFZ) have been combined) (Kissel et al., 2013); (e) equilibrium line altitude curve for Jostedalsbreen glacier, Norway, recording glacier retreat (Nesje et al., 2001); and (f) green line, Northwest Europe summer temperatures based on chironomid and pollen lake records from Scandinavia (Renssen et al., 2009); grey line is alkenone-based sea-surface temperature data from the Norwegian Sea (Jansen et al., 2008). 
overflow strength reduced long-term variations in the total flux of the Nordic sea overflows. We draw attention, however, to benthic carbon isotope data from the deep Northwest Atlantic (Keigwin and Boyle, 2000), which are consistent with a mid- to late Holocene weakening of the deep Nordic sea overflows.

\subsection{Holocene data-model comparison}

To help investigate factors controlling Nordic sea convection and I-S overflow strength during the Holocene, climate model simulations were performed using LOVECLIM version 1.2, a global model describing the coupled atmosphereocean-vegetation system (see the Supplement for details). In this study the results of four transient experiments that cover the last $9000 \mathrm{yr}$ are presented. The simulations were started at $9 \mathrm{ka}$ because before this time the influence of the Younger Dryas cold period may still have had an important influence on the climate through the long-term memory of the deep ocean. We forced all the simulations with orbital and GHG concentrations in line with the PMIP3 protocol (http://pmip3.1sce.ipsl.fr/), and then performed simulations sequentially adding the effects of Laurentide ice-sheet (LIS) meltwater, topographic and albedo effects, and finally GIS meltwater effects (see the Supplement for further details). The relatively low resolution of LOVECLIM means that although it is well suited for conducting numerous long transient experiments, it is unable to simulate processes accurately at the detail of the I-S overflow. It is therefore more appropriate to investigate the modelled changes in deep water formation, to investigate possible controls on Holocene I-S overflow strength.

There is good agreement between our model results and proxy data: for example, (1) the model simulates a delayed (relative to orbital forcing) early Holocene climate optimum, followed by a gradual cooling, albeit of a smaller amplitude than the proxy evidence suggests (Figs. 5e and 6c), (2) a $\sim 50 \%$ increase ( $\sim 0.02$ to $0.03 \mathrm{~Sv}$ freshwater equivalent) in the southward transport of sea ice through Fram Strait, from the Arctic to the Nordic seas, over the last $\sim 7 \mathrm{ka}$, consistent with evidence of increased deposition of ice rafted debris in the Fram Strait (Mueller et al., 2012) and the North Iceland Shelf (Moros et al., 2006; Andrews et al., 2009), which indicates a long-term increase in drift ice (ice bergs and multiyear sea ice) supply to the Nordic seas from $\sim 7 \mathrm{ka}$ to the late Holocene.

The model results suggest that the depth of convection in the Nordic seas was reduced by some $5-10 \%$ during the early and late Holocene, relative to the convection depth maximum between $\sim 7$ and $6 \mathrm{ka}(\sim 1200 \mathrm{~m}$, Fig. $6 \mathrm{~b})$, close to the regional HTM, supporting the inference that the longterm variability in I-S overflow strength was likely governed by changes in deep water formation. The decrease in model convection depth during the early Holocene was caused by the addition of meltwater into the North Atlantic from the

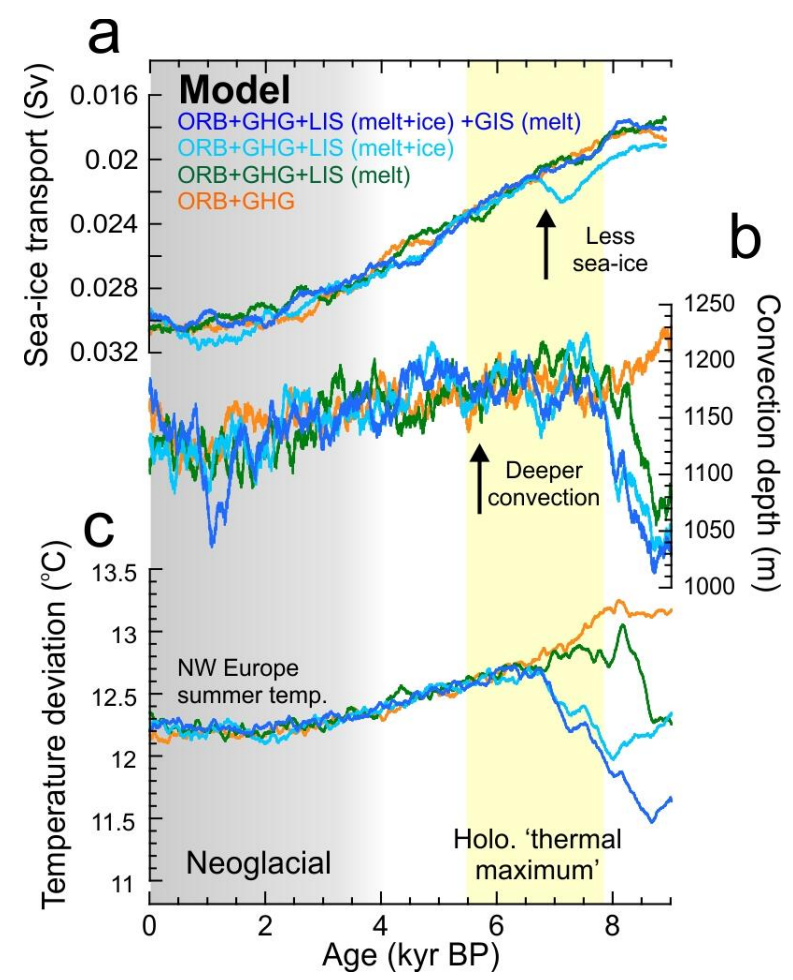

Fig. 6. Model outputs (499 yr smoothed) from Holocene simulations using LOVECLIM1.2. Simulations are as described in the Supplement and with a similar set-up as Renssen et al. (2009); abbreviations for the parameters included in each simulation are as follows: ORB, orbital insolation changes; GHG, Holocene changes in greenhouse gas concentrations; LIS (melt), modelled effects of the Laurentide ice-sheet meltwater; LIS (melt + ice) simulation includes LIS meltwater, topographic and albedo effects; GIS (melt), effects of Greenland ice-sheet meltwater. (a) Modelled southward transport of sea ice through Fram Strait. (b) Changes in the maximum winter convection depth in the Nordic seas. (c) Modelled July temperatures over Northwest Europe (Renssen et al., 2009).

remnant LIS, and indirect effects resulting from LIS-induced changes in albedo and atmospheric circulation (Renssen et al., 2009). It is probable that the reconstructed local minimum in I-S overflow strength at $9.5-8 \mathrm{ka}$ was caused by increased melting of the retreating LIS during this interval (Carlson et al., 2008; Hoffman et al., 2012). In contrast, the reduction in modelled convection depth over the past $\sim 7 \mathrm{ka}$ was primarily caused by enhanced sea ice and associated freshwater flux through Fram Strait, in response to increasing sea-ice cover in the Arctic due to orbitally controlled insolation changes. Feedback mechanisms between sea-ice cover and deep convection may have helped amplify these changes. The model simulations do not show any significant long-term variability in Arctic river fluxes that can be related to convection changes in the Nordic seas and I-S overflow strength. We note that the greater reduction in modelled convection depth during the early Holocene compared to the late Holocene contrasts with the most pronounced weakening of 
the I-S overflow occurring during the late Holocene. This may reflect a bias in the model's response to meltwater from the LIS, although numerous other factors could contribute to this apparent discrepancy between the two parameters (modelled convection depth and proxy reconstructed I-S overflow strength).

Compared to state-of-the-art general circulation models, the modern maximum AMOC strength of $24 \mathrm{~Sv}$ simulated by LOVECLIM is at the higher end of the spectrum. However, the AMOC's sensitivity to future greenhouse gas forcing scenarios in LOVECLIM is comparable to that of other models (Weaver et al., 2012). In the LOVECLIM simulations, the AMOC strength is reduced by $20-30 \%$ in the early Holocene due to the impact of the melting LIS and GIS, consistent with the reduction in Nordic sea convection depth shown in Fig. 6b. However, after $7 \mathrm{ka}$, the AMOC strength remains relatively stable unlike the convection depth, which is decreasing. This stable AMOC strength implies that convection activity increased at locations outside the Nordic seas, such as the Labrador Sea, similar to the results reported by Renssen et al. (2005).

\subsection{Future model simulations}

Based on our observed coupling between the decline in I$S$ overflow strength and the increase in Nordic sea drift-ice proxies, we are led to question whether the ongoing (http: //nsidc.org/arcticseaicenews/) (Stroeve et al., 2007), and projected, decline in Arctic sea ice (Solomon et al., 2007) may potentially alter I-S overflow strength, although observations and hindcast modelling results have not revealed any longterm change in I-S overflow strength over the past $\sim 50 \mathrm{yr}$ (Olsen et al., 2008).

Future transient simulations following the IPCC SRES A1B, A2 and B1 were performed using LOVECLIM to examine the possible behaviour of deep convection, and by inference, the I-S overflow (see Table 2 and the Supplement). All simulations were initiated from a Pre-Industrial control simulation that had reached a quasi-equilibrium state. These three scenarios were chosen because they cover the full range of 21st century anthropogenic GHG forcing defined by the IPCC, allowing for a wider perspective of future projections to be determined.

These simulations reveal a decrease in the export of Arctic sea ice into the Nordic seas via Fram Strait, which by itself would increase sea surface salinity in the Nordic seas and promote deep convection. However, warmer Nordic sea SSTs counteract the effects of the sea-ice changes on surface water density, preventing an overall increase in convection depth in any of our future scenario runs. Instead, under the high emissions scenarios A1B and A2, we observe a pronounced $\sim 40 \%$ reduction in the modelled maximum winter convection depth by the end of the 21 st century, primarily caused by warmer SSTs, consistent with the results of several earlier modelling studies (Gregory et al., 2005; Schmittner et al.,
Table 2. Modelled changes in March sea-surface salinity (SSS), temperature (SST), surface density, and maximum winter convection depth over the region $15-20^{\circ} \mathrm{E}, 76.25-78.75^{\circ} \mathrm{N}$ during the Holocene and under future IPCC emission scenarios.

\begin{tabular}{|c|c|c|c|c|c|c|}
\hline & & $\begin{array}{l}p \mathrm{CO}_{2} \\
(\mathrm{ppm})\end{array}$ & $\begin{array}{r}\text { SSS } \\
(\mathrm{psu})\end{array}$ & $\begin{array}{l}\text { SST } \\
\left({ }^{\circ} \mathrm{C}\right)\end{array}$ & $\begin{array}{r}\text { Surface } \\
\text { density } \\
\left(\mathrm{kg} \mathrm{m}^{-3}\right)\end{array}$ & $\begin{array}{l}\text { Convection } \\
\text { depth (m) } \\
\pm 2 \mathrm{SE}\end{array}$ \\
\hline $6 \mathrm{ka}^{\mathrm{a}, \mathrm{b}}$ & - & 265 & 35.09 & 2.65 & 1027.989 & $1194 \pm 40$ \\
\hline Pre-Industrial $^{\mathrm{a}}$ & - & 280 & 35.03 & 2.16 & 1027.983 & $1120 \pm 37$ \\
\hline $2070-2100 \mathrm{AD}$ & B1 & 533 & 35.13 & 4.10 & 1027.879 & $914 \pm 176$ \\
\hline $2070-2100 \mathrm{AD}$ & A1B & 657 & 35.10 & 4.47 & 1027.815 & $717 \pm 99$ \\
\hline $2070-2100 \mathrm{AD}$ & $\mathrm{A} 2$ & 725 & 35.09 & 4.68 & 1027.784 & $661 \pm 64$ \\
\hline
\end{tabular}

a $500 \mathrm{yr}$ averages and ${ }^{\mathrm{b}}$ using prescribed orbital parameters for $6 \mathrm{ka}$.

2005; Stouffer et al., 2006). The "competing" effect of SST also explains the difference in convection depths between the HTM (relatively deep) and late 21st century IPCC scenarios A1B and A2 (relatively shallow): both intervals are associated with a decreased flux of sea ice through Fram Strait, but the warmer predicted SSTs of the Nordic seas during the late 21 st century under IPCC scenarios A1B and A2, compared to the HTM, decrease surface water density and therefore reduce the depth of convection (Table 2 and the Supplement).

\section{Concluding remarks}

This study has demonstrated that grain size analyses in an extensive compilation of cores, forming a $1.2-2.3 \mathrm{~km}$ depth transect, can be used to constrain Holocene changes in both the strength and depth of the I-S overflow. By identifying the vertical migration (gradual deepening) of the I-S overflow over the South Iceland Rise/Bjorn Drift during the early Holocene, this approach enables the reconciliation of apparently conflicting long-term trends identified by earlier studies, based on individual cores (Hall et al., 2004; Praetorius et al., 2008; Thornalley et al., 2010; Hoogakker et al., 2011). The stacked proxy record indicates that I-S overflow increased through the early Holocene, albeit with a minimum at $\sim 9.5-8 \mathrm{ka}$. Peak I-S overflow strength occurred at $\sim 7 \mathrm{ka}$, followed by a gradual decline over the remainder of the Holocene. These changes were likely related to deep convection processes in the Nordic seas, which were affected by varying freshwater fluxes, during the early Holocene from remnant deglacial ice sheets, and the mid- to late Holocene from an orbitally induced increase in the export of Arctic sea ice.

We draw attention to the observation that the weakening of the I-S overflow over the last $\sim 7 \mathrm{ka}$ was not accompanied by a pronounced shoaling of the main flow axis of the overflow in a manner similar to that observed during the early Holocene. This may be a result of the different circulation regime of the high latitude North Atlantic during the early Holocene, when there was significant freshwater input from decaying glacial ice sheets, and which included weaker or 
absent LSW formation (Hillaire-Marcel et al., 2001), possibly a greater contribution of dense Lower Deep water (of southern origin) in the deep Northeast Atlantic (Hoogakker et al., 2011) and a contracted subpolar gyre (Thornalley et al., 2009). These processes would have altered the density structure of the water column south of the Greenland-Scotland Ridge and therefore possibly contributed to a shallow I-S overflow during the early Holocene. However, it is also possible that the different response of the I-S overflow during the early and late Holocene is linked to changes in the wind forcing of the overflow, with several studies presenting evidence of changes in atmospheric circulation over the North Atlantic during the mid- to late Holocene (O'Brien et al., 1995; Bond et al., 2001; Rimbu et al., 2003). The relatively low resolution of LOVECLIM does not permit us to investigate confidently the effects of such phenomena on the I-S overflow; however, we encourage future studies, using higher resolution models and the development of new, more robust constraints on past atmospheric circulation changes, to explore this topic and test the hypothesis that changes in the I-S overflow over the past $7 \mathrm{ka}$ were caused by a change in the wind forcing (e.g. Biastoch et al., 2003), in addition to thermohaline processes in the Nordic seas.

Several other questions still remain regarding Holocene ISOW flow, including the extent to which the flow speed of ISOW farther downstream is affected by entrainment and/or density changes in the overlying water column (e.g. by variations in eastward extent of LSW), as suggested by Boessenkool et al. (2007). It will therefore be fruitful to compare depth transects of flow speed proxy records at several locations along the path of the I-S overflow. Studies are also in progress to analyse high sedimentation rate core sites that will enable the investigation of whether or not there were significant changes in I-S overflow strength prior to observational records, specifically the end of the Little Ice Age $(\sim 1850 \mathrm{AD})$, when marked climate changes occurred in the Nordic seas, including a decrease in drift ice (Andrews et al., 2009).

\section{Supplementary material related to this article is available online at: http://www.clim-past.net/9/2073/ 2013/cp-9-2073-2013-supplement.pdf.}

\footnotetext{
Acknowledgements. The authors thank Paola Moffa-Sanchez for comments on an earlier version of the manuscript, Jake Gebbie for assistance plotting Fig. 4, and John Andrews, Olivier Marchal and Dan McCorkle for discussion. Funding was provided by NERC RAPID grant NER/T/S/2002/00436 to I. N. McCave, and a WHOI OCCI post-doctoral scholarship to D. J. R. Thornalley. Work on EW9302 cores was supported by NSF grant OCE0118001 to D. W. Oppo and J. F. McManus. The contributions of J. F. McManus and S. Praetorius were also supported in part by the Comer Research and Education Foundation. M. Blaschek,
}

F. J. Davies and H. Renssen are supported by the European Community's 7th Framework Programme FP7 2007/2013, Marie-Curie Actions, under Grant Agreement No. 10238111 CASE ITN.

Edited by: U. Mikolajewicz

\section{References}

Andrews, J. T., Darby, D., Eberle, D., Jennings, A. E., Moros, M., and Ogilvie, A.: A robust, multisite Holocene history of drift ice off northern Iceland: implications for North Atlantic climate, Holocene, 19, 71-77, doi:10.1177/0959683608098953, 2009.

Bacon, S.: Decadal variability in the outflow from the Nordic seas to the deep Atlantic Ocean, Nature, 394, 871-874, doi:10.1038/29736, 1998.

Bianchi, G. G. and McCave, I. N.: Holocene periodicity in North Atlantic climate and deep-ocean flow south of Iceland, Nature, 397, 515-517, 1999.

Bianchi, G. G. and McCave, I. N.: Hydrography and sedimentation under the deep western boundary current on Bjorn and Gardar Drifts, Iceland Basin, Mar. Geol., 165, 137-169, 2000.

Bianchi, G. G., Hall, I. R., McCave, I. N., and Joseph, L.: Measurement of the sortable silt current speed proxy using the sedigraph 5100 and Coulter Multisizer IIe: Precision and accuracy, Sedimentology, 46, 1001-1014, 1999.

Biastoch, A., Kase, R. H., and Stammer, D. B.: The sensitivity of the Greenland-Scotland Ridge overflow to forcing changes, J. Phys. Oceanogr., 33, 2307-2319, doi:10.1175/15200485(2003)033<2307:tsotgr > 2.0.co;2, 2003.

Bilodeau, G., Devernal, A., and Hillairemarcel, C.: Benthic foraminiferal assembalges in Labrador Sea sediments - relations with deep-water mass changes since deglaciation, Can. J. Earth Sci., 31, 128-138, doi:10.1139/e94-011, 1994.

Boessenkool, K. P., Hall, I. R., Elderfield, H., and Yashayaev, I.: North Atlantic climate and deep-ocean flow speed changes during the last 230 years, Geophys. Res. Lett., 34, L13614, doi:10.1029/2007g1030285, 2007.

Bond, G., Kromer, B., Beer, J., Muscheler, R., Evans, M. N., Showers, W., Hoffmann, S., Lotti-Bond, R., Hajdas, I., and Bonani, G.: Persistent solar influence on north Atlantic climate during the Holocene, Science, 294, 2130-2136, 2001.

Carlson, A. E., Legrande, A. N., Oppo, D. W., Came, R. E., Schmidt, G. A., Anslow, F. S., Licciardi, J. M., and Obbink, E. A.: Rapid early Holocene deglaciation of the Laurentide ice sheet, Nat. Geosci., 1, 620-624, doi:10.1038/ngeo285, 2008.

Delworth, T. L. and Zeng, F.: Multicentennial variability of the Atlantic meridional overturning circulation and its climatic influence in a 4000 year simulation of the GFDL CM2.1 climate model, Geophys. Res. Lett., 39, L13702, doi:10.1029/2012g1052107, 2012.

Dickson, R.: Flow statistics from long-term current-meter moorings: the global data-set in January 1989, World Climate Research Programme 30 (WMO/TD-No.337), 1989.

Ellison, C. R. W., Chapman, M. R., and Hall, I. R.: Surface and deep ocean interactions during the cold climate event 8200 years ago, Science, 312, 1929-1932, doi:10.1126/science.1127213, 2006.

Fagel, N. and Mattielli, N.: Holocene evolution of deep circulation in the northern North Atlantic traced by $\mathrm{Sm}, \mathrm{Nd}$ and $\mathrm{Pb}$ isotopes 
and bulk sediment mineralogy, Paleoceanography, 26, PA4220, doi:10.1029/2011pa002168, 2011.

Gherardi, J. M., Labeyrie, L., Nave, S., Francois, R., McManus, J. F., and Cortijo, E.: Glacial-interglacial circulation changes inferred from (231) $\mathrm{Pa} /(230) \mathrm{Th}$ sedimentary record in the North Atlantic region, Paleoceanography, 24, PA2204, doi:10.1029/2008pa001696, 2009.

Giraudeau, J., Grelaud, M., Solignac, S., Andrews, J. T., Moros, M., and Jansen, E.: Millennial-scale variability in Atlantic water advection to the Nordic Seas derived from Holocene coccolith concentration records, Quaternary Sci. Rev., 29, 1276-1287, doi:10.1016/j.quascirev.2010.02.014, 2010.

Gregory, J. M., Dixon, K. W., Stouffer, R. J., Weaver, A. J., Driesschaert, E., Eby, M., Fichefet, T., Hasumi, H., Hu, A., Jungclaus, J. H., Kamenkovich, I. V., Levermann, A., Montoya, M., Murakami, S., Nawrath, S., Oka, A., Sokolov, A. P., and Thorpe, R. B.: A model intercomparison of changes in the Atlantic thermohaline circulation in response to increasing atmospheric $\mathrm{CO}_{2}$ concentration, Geophys. Res. Lett., 32, doi:10.1029/2005g1023209, 2005.

Hall, I. R., Bianchi, G. G., and Evans, J. R.: Centennial to millennial scale Holocene climate-deep water linkage in the North Atlantic, Quaternary Sci. Rev., 23, 1529-1536, doi:10.1016/j.quascirev.2004.04.004, 2004.

Hansen, B. and Osterhus, S.: North Atlantic-Nordic Seas exchanges, Prog. Oceanogr., 45, 109-208, 2000.

Hansen, B., Turrell, W. R., and Osterhus, S.: Decreasing overflow from the Nordic seas into the Atlantic Ocean through the Faroe Bank Channel since 1950, Nature, 411, 927-930, 2001.

Haskell, B. J., Johnson, T. C., and Showers, W. J.: Fluctuations in deep western North Atlantic circulation on the Blake Outer Ridge during the last deglaciation, Paleoceanography, 6, 12-31, 1991.

Hillaire-Marcel, C., de Vernal, A., Bilodeau, G., and Weaver, A. J.: Absence of deep-water formation in the Labrador Sea during the last interglacial period, Nature, 410, 1073-1077, 2001.

Hoffman, J. S., Carlson, A. E., Winsor, K., Klinkhammer, G. P., LeGrande, A. N., Andrews, J. T., and Strasser, J. C.: Linking the $8.2 \mathrm{ka}$ event and its freshwater forcing in the Labrador Sea, Geophys. Res. Lett., 39, doi:10.1029/2012gl053047, 2012.

Hoogakker, B. A. A., Chapman, M. R., McCave, I. N., Hillaire-Marcel, C., Ellison, C. R. W., Hall, I. R., and Telford, R. J.: Dynamics of North Atlantic Deep Water masses during the Holocene, Paleoceanography, 26, PA4214, doi:10.1029/2011pa002155, 2011.

Huybers, P. and Wunsch, C.: Paleophysical Oceanography with an Emphasis on Transport Rates, in: Annual Review of Marine Science, Annual Review of Marine Science, 2, 1-34, 2010.

Jansen, E., Andersson, C., Moros, M., Nisancioglu, K., Nyland, B., and Telford, R. J.: The early to mid-Holocene thermal optimum in the North Atlantic, in: Natural Climate Variability and Global Warming - A Holocene Perspective, edited by: Battarbee, R. W. and Binney, H. A., Wiley-Blackwell, Chichester, 123-137, 2008.

Keigwin, L. D. and Boyle, E.: Detecting Holocene changes in thermohaline circulation, P. Natl. Acad. Sci., 97, 1343-1346, 2000.

Kissel, C., Laj, C., Piotrowski, A. M., Goldstein, S. L., and Hemming, S. R.: Millennial-scale propagation of Atlantic deep waters to the glacial Southern Ocean, Paleoceanography, 23, PA2102, doi:10.1029/2008pa001624, 2008.
Kissel, C., Laj, C., Mulder, T., Wandres, C., and Cremer, M.: The magnetic fraction: A tracer of deep water circulation in the North Atlantic, Earth Planet. Sc. Lett., 288, 444-454, doi:10.1016/j.eps1.2009.10.005, 2009.

Kissel, C., Van Toer, A., Laj, C., Cortijo, E., and Michel, E.: Variations in the strength of the North Atlantic bottom water during Holocene, Earth Planet. Sc. Lett., 369-370, 248-259, doi:10.1016/j.epsl.2013.03.042, 2013.

Kristjansdottir, G. B., McCave, I. N., and Bryant, C.: AMS C-14 ages of coretops collected on RRS Charles Darwin cruise CD159, July 2004, N. Atlantic, for the NERC RAPID programme, Godwin Laboratory for Palaeoclimate Research, Department of Earth Sciences, University of Cambridge, doi:10.1594/PANGAEA.773254, 2011.

Ledbetter, M. T.: A late Pleistocene time-series of bottom-current speed in the Vema Channel, Palaeogeogr. Palaeocl., 53, 97-105, doi:10.1016/0031-0182(86)90040-4, 1986.

Lynch-Stieglitz, J., Curry, W. B., and Lund, D. C.: Florida Straits density structure and transport over the last 8000 years, Paleoceanography, 24, PA3209, doi:10.1029/2008pa001717, 2009.

Marchal, O., Cacho, I., Stocker, T. F., Grimalt, J. O., Calvo, E., Martrat, B., Shackleton, N., Vautravers, M., Cortijo, E., van Kreveld, S., Andersson, C., Koc, N., Chapman, M., Sbaffi, L., Duplessy, J. C., Sarnthein, M., Turon, J. L., Duprat, J., and Jansen, E.: Apparent long-term cooling of the sea surface in the northeast Atlantic and Mediterranean during the Holocene, Quaternary Sci. Rev., 21, 455-483, doi:10.1016/s0277-3791(01)00105-6, 2002.

Mayewski, P. A., Rohling, E. J., Stager, J. C., Karlen, W., Maasch, K. A., Meeker, L. D., Meyerson, E. A., Gasse, F., van Kreveld, S., Holmgren, K., Lee-Thorp, J., Rosqvist, G., Rack, F., Staubwasser, M., Schneider, R. R., and Steig, E. J.: Holocene climate variability, Quaternary Res., 62, 243-255, 2004.

McCave, I. N. and Hall, I. R.: Size sorting in marine muds: Processes, pitfalls, and prospects for paleoflowspeed proxies, Geochem. Geophys. Geosyst., 7, Q10N05, doi:10.1029/2006gc001284, 2006.

McManus, J. F., Francois, R., Gherardi, J. M., Keigwin, L. D., and Brown-Leger, S.: Collapse and rapid resumption of Atlantic meridional circulation linked to deglacial climate changes, Nature, 428, 834-837, 2004.

Moros, M., Andrews, J. T., Eberl, D. D., and Jansen, E.: Holocene history of drift ice in the northern North Atlantic: Evidence for different spatial and temporal modes, Paleoceanography, 21, PA2017, doi:10.1029/2005pa001214, 2006.

Mueller, J., Werner, K., Stein, R., Fahl, K., Moros, M., and Jansen, E.: Holocene cooling culminates in sea ice oscillations in Fram Strait, Quaternary Sci. Rev., 47, 1-14, doi:10.1016/j.quascirev.2012.04.024, 2012.

Nesje, A., Matthews, J. A., Dahl, S. O., Berrisford, M. S., and Andersson, C.: Holocene glacier fluctuations of Flatebreen and winter-precipitation changes in the Jostedalsbreen region, western Norway, based on glaciolacustrine sediment records, Holocene, 11, 267-280, doi:10.1191/095968301669980885, 2001.

O’Brien, S. R., Mayewski, P. A., Meeker, L. D., Meese, D. A., Twickler, M. S., and Witlow, S. I.: Complexity of Holocene climate as reconstructed from a Greenland ice core, Science, 270, 962-964, 1995. 
Olsen, A. and Ninnemann, U.: Large delta C-13 Gradients in the Preindustrial North Atlantic Revealed, Science, 330, 658-659, doi:10.1126/science.1193769, 2010.

Olsen, S. M., Hansen, B., Quadfasel, D., and Osterhus, S.: Observed and modelled stability of overflow across the GreenlandScotland ridge, Nature, 455, 519-535, doi:10.1038/nature07302, 2008.

Oppo, D. W., McManus, J. E., and Cullen, J. L.: Deepwater variability in the Holocene epoch, Nature, 422, 277-278, 2003.

Porter, S. C. and Denton, G. H.: Chronology of Neoglaciation in the North American Cordillera, Am. J. Sci., 265, 177-210, 1967.

Praetorius, S. K., McManus, J. F., Oppo, D. W., and Curry, W. B.: Episodic reductions in bottom-water currents since the last ice age, Nat. Geosci., 1, 449-452, doi:10.1038/ngeo227, 2008.

Price, J. F. and Baringer, M. O.: Outflows and Deep-water production by marginal seas, Prog. Oceanogr., 33, 161-200, doi:10.1016/0079-6611(94)90027-2, 1994.

Rasmussen, T. L., Backstrom, D., Heinemeier, J., Klitgaard Kristensen, D., Knutz, P. C., Kuijpers, A., Lassen, S., Thomsen, E., Troelstra, S. R., and van Weering, T. C. E.: The Faroe-Shetland Gateway: Late Quaternary water mass exchange between the Nordic Seas and the northeastern Atlantic, Mar. Geol., 188, 165192, 2002.

Renssen, H., Goosse, H., and Fichefet, T.: Contrasting trends in north Atlantic deep-water formation in the Labrador Sea and Nordic Seas during the Holocene, Geophys. Res. Lett., 32, L08711, doi:10.1029/2005g1022462, 2005.

Renssen, H., Seppa, H., Heiri, O., Roche, D. M., Goosse, H., and Fichefet, T.: The spatial and temporal complexity of the Holocene thermal maximum, Nat. Geosci., 2, 410-413, doi:10.1038/ngeo513, 2009.

Rimbu, N., Lohmann, G., Kim, J. H., Arz, H. W., and Schneider, R.: Arctic/North Atlantic Oscillation signature in Holocene sea surface temperature trends as obtained from alkenone data, Geophys. Res. Lett., 30, 1280, doi:10.1029/2002GL016570, 2003.

Risebrobakken, B., Jansen, E., Andersson, C., Mjelde, E., and Hevroy, K.: A high-resolution study of Holocene paleoclimatic and paleoceanographic changes in the Nordic Seas, Paleoceanography, 18, 1017, doi:10.1029/2002PA000764, 2003.

Saunders, P. M.: The flux of dense cold overflow water southeast of Iceland, J. Phys. Oceanogr., 26, 85-95, doi:10.1175/15200485(1996)026<0085:tfodco > 2.0.co;2, 1996.

Schmittner, A., Latif, M., and Schneider, B.: Model projections of the North Atlantic thermohaline circulation for the 21st century assessed by observations, Geophys. Res. Lett., 32, L23710, doi:10.1029/2005g1024368, 2005.

Seager, R., Battisti, D. S., Yin, J., Gordon, N., Naik, N., Clement, A. C., and Cane, M. A.: Is the Gulf Stream responsible for Europe's mild winters?, Q. J. Roy. Meteorol. Soc., 128, 2563-2586, 2002.

Shor, A. N.: Bottom currents and abyssal sedimentation processes south of Iceland, $\mathrm{PhD}$, Woods Hole Oceanographic Institution, 246 pp., 1980.

Smith, R. S. and Gregory, J. M.: A study of the sensitivity of ocean overturning circulation and climate to freshwater input in different regions of the North Atlantic, Geophys. Res. Lett., 36, L15701, doi:10.1029/2009g1038607, 2009.
Solignac, S., de Vernal, A., and Hillaire-Marcel, C.: Holocene seasurface conditions in the North Atlantic - contrasted trends and regimes in the western and eastern sectors (Labrador Sea vs. Iceland Basin), Quaternary Sci. Rev., 23, 319-334, doi:10.1016/j.quascirev.2003.06.003, 2004.

Solomon, S., Qin, D., Manning, M., Chen, Z., Marquis, M., Averyt, K., Tgnor, M., and Miller, H.: IPCC, 2007: Climate Change 2007: The Physical Science Basis. Contribution of Working Group I to the Fourth Assessment Report of the Intergovernmental Panel on Climate Change, Cambridge University Press, Cambridge, United Kingdom and New York, NY, USA, 996 pp., 2007.

Stouffer, R. J., Yin, J., Gregory, J. M., Dixon, K. W., Spelman, M. J., Hurlin, W., Weaver, A. J., Eby, M., Flato, G. M., Hasumi, H., Hu, A., Jungclaus, J. H., Kamenkovich, I. V., Levermann, A., Montoya, M., Murakami, S., Nawrath, S., Oka, A., Peltier, W. R., Robitaille, D. Y., Sokolov, A., Vettoretti, G., and Weber, S. L.: Investigating the causes of the response of the thermohaline circulation to past and future climate changes, J. Climate, 19, 1365-1387, doi:10.1175/jcli3689.1, 2006.

Stroeve, J., Holland, M. M., Meier, W., Scambos, T., and Serreze, M.: Arctic sea ice decline: Faster than forecast, Geophys. Res. Lett., 34, L09501, doi:10.1029/2007g1029703, 2007.

Thornalley, D. J. R., Elderfield, H., and McCave, I. N.: Holocene oscillations in temperature and salinity of the surface subpolar North Atlantic, Nature, 457, 711-714, doi:10.1038/nature07717, 2009.

Thornalley, D. J. R., Elderfield, H., and McCave, I. N.: Intermediate and deep water paleoceanography of the northern North Atlantic over the past 21,000 years, Paleoceanography, 25, PA1211, doi:10.1029/2009PA001833, 2010.

Thornalley, D. J. R., Barker, S., Becker, J., Knorr, G., and Hall, I. R.: Abrupt changes in ocean circulation during the onset of full glacial conditions, Paleoceanography, 28, 253-262, doi:10.1002/palo.20025, 2013.

Van Aken, H. M.: Currents and current variability in the Iceland Basin, Neth. J. Sea Res., 33, 135-145, 1995.

Vellinga, M. and Wood, R. A.: Global climatic impacts of a collapse of the Atlantic thermohaline circulation, Climatic Change, 54, 251-267, doi:10.1023/a:1016168827653, 2002.

Wanner, H., Beer, J., Buetikofer, J., Crowley, T. J., Cubasch, U., Flueckiger, J., Goosse, H., Grosjean, M., Joos, F., Kaplan, J. O., Kuettel, M., Mueller, S. A., Prentice, I. C., Solomina, O., Stocker, T. F., Tarasov, P., Wagner, M., and Widmann, M.: Mid- to Late Holocene climate change: an overview, Quaternary Sci. Rev., 27, 1791-1828, doi:10.1016/j.quascirev.2008.06.013, 2008.

Wanner, H., Solomina, O., Grosjean, M., Ritz, S. P., and Jetel, M.: Structure and origin of Holocene cold events, Quaternary Sci. Rev., 30, 3109-3123, doi:10.1016/j.quascirev.2011.07.010, 2011.

Weaver, A. J., Sedlacek, J., Eby, M., Alexander, K., Crespin, E., Fichefet, T., Philippon-Berthier, G., Joos, F., Kawamiya, M., Matsumoto, K., Steinacher, M., Tachiiri, K., Tokos, K., Yoshimori, M., and Zickfeld, K.: Stability of the Atlantic meridional overturning circulation: A model intercomparison, Geophys. Res. Lett., 39, 253-262, doi:10.1029/2012g1053763, 2012. 